\title{
ЧАЮВАННЯ 3 МЕДУЗОЮ ГОРГОНОЮ, АБО ПРО ВИВЧЕННЯ ВИВЧЕННЯ ТЕОРІЇ ЛІТЕРАТУРИ
}

(рецензія на навчальний посібник: О.Д.Сінченко. Комунікативні стратегії в теорії літератури: автор, текст, читач: Навчальний посібник / Олексій

Сінченко. - К.: Логос, 2015. -170 с.)

Чи пригадуєте Ви, шановні колеги-викладачі, свої лекції для студентівфілологів на першому курсі, коли іноді губишся: продовжувати виклад чи коментувати кожен термін? Ще трагічніше, якщо застиглий погляд або ж відчайдушні гримаси бачимо на курсі III-IV при називанні яких-небудь безневинних антиципації чи когезії.... I, дійшовши до магістратури, виконавши бакалаврську роботу, що, здавалося б, забезпечує знання засад філологічної методології, не кожен студент впевнено почуває себе на теренах численних шкіл і напрямів, не завжди може пояснити, як саме він досліджував текст, чому спирався на ті, а не інші студії своїх більш чи менш відомих попередників.

Отже, як виявляється, викладання літературознавчих дисциплін, а зокрема курсів методологічного плану, що переважно з'являються на магістратурі, $\epsilon$ річ для викладача травматична, а для студента переважно марудна чи й небезпечна, як-от чаювання з Медузою Горгоною, коли кожна мить загрожує скам'янінням, і порятувати може лише втеча, але з вихованості раз за разом підносиш чашку до уст, лише мріючи про те, щоб чай якнайшвидше закінчився.

Зі мною, думаю, 3 легкою душею погодиться переважна більшість викладачів, хоча, ймовірно, кращі зі студентів (не називатиму відсоток таких у групах, бо ж буває по-різному) будуть відчайдушно сперечатися, адже вважають, що володіння термінологічним апаратом (загальнонауковим чи філологічним) є очевидним і не підлягає обговоренню. Але проблема від того не зникає.

Чи можемо дозволити собі нарікати на те, що наші студенти приходять зі школи недостатньо підготовлені? Це незаперечний факт! Формально шкільна програма, попри окремі дискусійні моменти, достатньо насичена різноманітними поняттями, без яких неможливе засвоєння не просто суми знань, а й становлення особистості, здатної мислити. У реальності мало хто 3 учнів із задоволенням аналізує літературний твір, не користуючись штампами i кліше на зразок «видатний внесок у щось...» або ж «високохудожній витвір мистецтва», мало хто оперує термінами автор, текст, читач, розуміючи, що за ними стоїть насправді. А імена скількох літературознавців чули школярі навіть профільних класів?

Проблеми середньої освіти не розглядає хоча б принагідно лише ледачий, можемо нарікати і на вади підготовки вчителів (самі ж їх готуємо!), і на зорієнтованість учня на зовнішнє незалежне оцінювання, а не на розвиток критичного мислення. Парадоксально, що програма ЗНО насправді містить достатній обсяг, практично повний спектр базових літературознавчих понять, 
у перших рядках іï вказано, що «учасник ЗНО повинен вміти аналізувати літературний твір», далі йде перелік справді найважливіших, суттєвих понять, які потім так чи інакше будуть відображені у тестових завданнях.

Тоді, якщо за задумом підготовка має бути якісною, не зовсім зрозуміло, чому ж настільки важко домогтися від студента бажаного. Можливо, є такі специфічні види діяльності - а серед них, 3 моєї точки зору, одне із скромних, проте помітних місць, посідає розуміння художнього твору, яким або ж (на думку деяких снобів від філологіï) не можна навчити, або ж навчити незрівнянно складно. Теоретико-літературні поняття як компоненти аналізу тексту, що показує досвід, чудово засвоюють учні, здібні до математичних наук, цьому сприяє їхнє структуроване мислення.

Перед нами насправді непросте завдання - виховати і навчити студентівфілологів, чи не у рекордні терміни посвятивши їх у механізми дослідження художнього слова, i водночас подолати власні упередження щодо недоступності для більшості 3 них програми-максимум: вимагається повноцінне володіння категоріальним апаратом та освоєння традиційних i сучасних методологій.

Серйозний крок до розв'язання цієї задачі - посібник Олексія Сінченка «Комунікативні стратегії в теорії літератури: автор, текст, читач». Автор декларує дещо скромніші цілі - допомогти майбутньому філологу «сформувати власну метамову, засвоїти необхідний термінологічний мінімум» (с. 4). Уже з перших рядків він запрошує до роздумів, звертаючись до читача без поблажливості, і на мить не припускаючи, що його виклад не примусить мислити і аналізувати. Це досягається не лише добором наукового матеріалу, а й не ускладненим штучно, прозорим стилем написання (окрема вдячність редактору).

Структура посібника не переобтяжена, усі чотири розділи («Автор», «Текст», «Читач», «Горизонт сподівань») побудовані за єдиним принципом. Вони містять дві складові: теоретичний матеріал - відповідно до смислової домінанти, i завдання для самопідготовки (питання до теми, теми рефератів $\mathrm{i}$ доповідей, першоджерела для конспектування, схема опрацювання критичної літератури та список рекомендованої літератури). Список рекомендованої літератури оптимально збалансований, термінологічний словник висвітлює комплекс термінів, хоча деякі 3 них прокоментовано дещо занадто розлого для словника, проте такі детальні пояснення цілком вмотивовані форматом навчального посібника. Імпонує запропонована схема аналізу критичної літератури, передусім тому, що науковець орієнтує студентів на комплексне i аналітичне ii прочитання. Окрім того, автор максимально активізує дослідницькі навички магістрантів, особливо вагомим у цьому плані $є$ пункт 4, у якому пропонується виявити складнощі, що спіткали при опрацюванні першоджерел та продемонструвати шляхи їх подолання.

Безумовно, посібник буде дуже корисний як студентам, так і викладачам, передусім завдяки зверненню до актуальних проблем літературознавства, завдяки їх коректній i точній інтерпретації, завдяки можливості 
Синопсис: текст, контекст, медіа, № 3 (11), 2015

поспілкуватися 3 автором як обізнаною в сперечливих питаннях науки особистістю.

I тепер не так вже й страшно буде чаювати 3 Горгоною - вона примружила свої зловісні очі, задоволено смакуючи разом із нами духмяний чай пізнання, трохи гіркуватий від досвіду попередніх поколінь науковців, але ж повний такого насиченого, істинно філологічного смаку...

Олена Сременко 